\title{
Some Comments on the Yamagata Proposition
}

\author{
山形博士の提案に対する意見
}

\author{
Yuan Chuan LEE \\ The Johns Hopkins University, Department of Biology, \\ Baltimore, MD 21218, USA, FAX: 1-301-338-8716
}

The idea presented by Dr. Yamagata in the Glycoforum [TIGG (1990) 2, 526-533] is a refreshing proposition aimed to alleviate difficulties of structural determination in glycoconjugates. His idea is pleasantly close to that held by myself, and I am quite pleased that Dr. Yamagata has enunciated the notion so clearly in this forum. The main point forwarded by Dr. Yamagata is that structural characterization of oligosaccharides should be made easier and less painful. Today, far too many laboratories are spending too much time in redundant effort of characterizing the known oligosaccharides. Easing the pain of the structural characterization is on the mind of practically everyone, and we should openly discuss how we can accomplish this. I believe that this forum is the most suited stage for this sort of discussion.

We are accustomed to regard monosaccharides (such as galactose) as basic structural units. In reality, by "galactose" we mean an aggregate of carbons, hydrogens, and oxygens arranged in certain ways which is distinct from "mannose" or "glucose" by the ways of arranging these atoms. What Dr. Yamagata is proposing is to expand the size of the aggregate unit of comparison to oligosaccharides, which are aggregates of sugar residues. Dr. Yamagata lists PMR data as well as chromatographic data as the bases of comparison. Comparing an unknown oligosaccharide with the known oligosaccharides is far more complicated and difficult than comparison amongst monosaccharides. A staggering number of structures will arise if one considers all possible oligosaccharides. This feature, which some carbohydrate researchers boast as "a wealth of information storage possibility", is at the same time a tremendous handicap for clear structural elucidation and identification.

Most carbohydrate researchers justifiably trust PMR spectral data than HPLC data, because PMR spectra enable one to compare an unknown with reference compounds using many signal peaks at the same time. Moreover, PMR data are highly reproducible, quite independent on instrumentation or operator. Chemical shift values obtained with a $300-\mathrm{MHz}$ spectrometer from one manufacturer at one location are quite close to those obtained with a $500-\mathrm{MHz}$ instrument of another manufacturer operated in another location. Dr. Yamagata is right in placing a great emphasis on PMR in his proposal.

Unfortunately the HPLC data for oligosaccharides do not receive as high a respect as PMR. At the present stage of
TIGG(1990) 2,526-533のグライコフォーラムの山形博士の

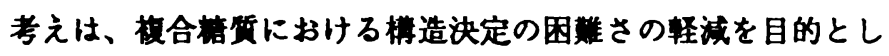
た斬新な主镸てある。彼の考えは、恰快なことであるか、私自 身によって考えられたものに近く、山形博士がこのフォーラム においてその啭念を明確にされたことを私は大変嬉しく思う。 山形博士によって主張された主な点はオリコ榶の構造決定はよ り「整痡、安楽」になされるべきであるということである。今 日、余りにも多くの研究室が既知のオリコ榶同定という重襍の 仕事に余りにも多くの時間を费やしている。桃造決定の苦痡を 和らげる事は殆と詮てもが心に泽かべる事であり、我々はこれ を如何に成し遂げるかをオーブンに討論すべきでる。私はこ のフォーラムがこの種の識詥に最も適した場であると思う。

我々は単榶（例えばカララクトース）を基本的な棈造単位と 見なす事に惯らされている。実際“ガラクトース”と言う単語 によって我々は炭素、水素、酸素が“マンノース”ゃ“グコ 一ス”とは原子の配列の仕方で異なっている一つの集合を意味 する。山形博士が提案しておられるのは比較の集合単位をオリ コ糖へ拡張しようというものである。ここで言うオリコ棱とは 耛合単榶残基の集合でる。山形博士は比較の基礎にクロマト データとMRデータを挙げておられる。未知のオリコ棺を既知 のオリコ榶と比较する問題は単榶で比较するより造かに複雑で あり、困䙵である。もし全ての可能なオリコ榶を考えるなら肝 を洪す样な数の構造が生じる。一部の榶質研究者が脰かな情報 の眝藏の可能性として自慢する特色は、同時に明確な構造を同 定するのに途方もないハンティーキャッフとなる。

大抵の糖質研究者はPMRスペクトルデータは同時に多くの シグナルピークを使って基準化合物と末知の化合物と比較でき るので、HPLCデータよりもPMRスベクトルの方をより信頼す ろ。又、実际にPMRデータは極めて再現性があり、枇器、オへ レーターに左右されない。ある一つのメーカーのある場所にあ る300 MHzのPMRスベクトロメーターを用いて得られたケミカ ルシフトは他の地域の他のメーカーの500 $\mathrm{MHz}$ の機器で得られ たものとは非常に近い。山形博士が彼の提案てPMRを非常に强 調しておられるのは正しい。

残念ながらオリコ榶のHPLCデータはPMRのような高い評 価を受けていない。現在の発展段階ではHPLCデータは変わり 易い。これらのデータはメーカー、カラムの古さ、あるいは機 䅦（例えばグラジェントの正確さ、再現性）によって影整され 
development, HPLC data are highly variable. They are influenced by the manufacturer or the age of the column or by the instrumentation (e.g., accuracy and reproducibility in gradient generation). This led to Dr. Noriko Takahashi's rather pessimistic reaction to include the HPLC data in a database as suggested by Dr. Yamagata[TIGG (1991)3, 56-57]. However, in our real life, some oligosaccharides are obtainable only in too small a quantity for reliable PMR analyses, and chromatographic methods may be the only way available for characterization.

To cope with the imperfection of the HPLC data, the researchers will have to use some temporary remedial measures. First, the degree of retention can be expressed with an internal scale, such as "glucose unit," to adjust for minor variations in separation conditions. This is being practiced by at least two research groups already, but some other convenient series compounds can be used instead. Secondly, more than one separation method (e.g., "2-D mapping" or a combination of high performance capillary electrophoresis and HPLC) can be used to increase the possibility of correct identification. Even if the separation could be performed reproducibly, the use of multiple separation methods is necessary. There are perhaps a few hundred well characterized oligosaccharides from glycoproteins, and just as many for the glycolipids. No single existing separation method can separate them all in a single run of a reasonable duration at a reasonable sensitivity. Finally, one can also use secondary steps of digesting the unknown sample (perhaps partially characterized already) with enzymes or adsorbing it on lectins. These approaches have been mentioned by Dr. Yamagata. In a number of the authoritative papers, carbohydrate structural determinations were performed solely dependent on lectins and enzymes and co-chromatography with reference compounds without the aid of PMR. There are some systematic application of plant lectins for a reasonable classification of oligosaccharides. The ideal database may also contain the reactions of an oligosaccharides towards lectins. The results of exo-glycosidases are usually predictable and clear and there is no need to enter such results into a database.

The currently unsatisfactory status of the HPLC methods of oligosaccharide characterization should not discourage us from entering the available HPLC data on a suitable database. There is nothing inherently wrong with the notion of comparing an unknown compound with known reference compounds using HPLC or other efficient separation methods. This is how amino acids and sugars are "identified." By having the HPLC data organized into a database, more researchers would use them and steady improvement should result from it. The currently popular PMR data library for oligosaccharides from glycoproteins is essentially built and used in this fashion. Most of the assignment is basically empirical in nature, and is frequently revised as new data are provided. We should not forget that in the early stage of PMR development, the values of
る。この為に山形博士の提案によろデーターベースにHPLCテ 一タを組み入れる事に対する高橋博士の御意見がなされた。し かしながら、実除は、信頼すべきPMR分析をするには余りにも 少ない田のオリコ榶しか得られない時は、クロマトグラフィー か、電気泳動が唯一の方法でしかい。

HPLCテータの不完全に対応するには研究者は一時的な湘 定を用いなければならない。先ず第一に保持時間の度合は別な 条件下てのマイナーな变化を補正する为に“グルコース単位” のような内部スケールで表現される。これは少なくとも二つの 研究クルーブによって既に実行されつつあるが、その代わりに 他の便利な一連の化合物が使用されてもよい。第二に一つ以上 の分法（例えば“2-Dマッビング” ヤ高性能ソーン電気泳動 とHPLCとの組合せ）は正しい同定の可能性を高める。たとえ 分彯再现性よくなされても多岐の分法法は必要である。多 分、糖タンパクから既に数百のオリコ榶が同定されており、そ れと匹效する数のオリコ榶が榶脂犋から得られて居る。現存す ろ如何なる分法も適当な感度で一回の分析時間内にこれらの

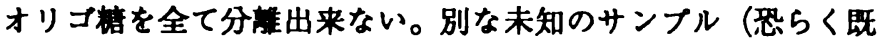
に部分的には同定されている）を酳素で消化するかあるいはレ クチンに吸着させる二次的手段を用いることが出来る。これら の方法は山形博士によっても言及されている。数多くの檴威的 論文て岸水化物の棈造決定はPMRの助けなしに、レクチンと醉 素と標準物斦とのコークロマトグラフィーにのみ传存して行わ れた。植物レクチンのオリコ榶の合理的な分類への系統的な応 用が幾つかある。理想的なデータベースはオリゴ榶のレクチン への反応性をも含むことができる。エキソグリコシダーゼによ る䊅果は通常断定的に明確であり、これらの耛果をデータベー スに入れる必要はないと思う。

現在の不满足なオリコ格同定のHPLC法の状態にもかかわ らず、我々は現在利用できるHPLCデータを適当なデータベー

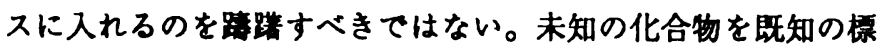
䒨物質とHPLC等の効率良い分法方法てって比较する概念は 元来何も間遣った事ではない。これによてアミノ酸と榶が同 定”されている。HPLCデータベースに整理することによっ て、より多くの研究者はそれらを利用し、その䊅果しっかりし た進歩が策かれる事は予想出来る。榶タンバクからのオリコ榶 の現存のPMRデータライブラリーは実験的に棈築され、このよ うに使用されている。大抵のアサインメントは元来経験的なも のであり、新しいデー夕が供給されると度々改訂される。PMR の発展の初期においてケミカルシフトは再現性がなく、かつ大 変正磪でもなかったことを忘れるべきではない。我々はHPLC もそのように発展することを期待する。

仮に、もし世界中の全ての榙質研究者か“标泮”HPLCカラ ムを供給され、そしてもしカラムがある特定の性能試験をバス しない時は何時でも無料で交换されることが出来ると、仮定し 
chemical shift are neither very reproducible nor very accurate also. One hopes that HPLC would also evolve in such a way.

Hypothetically, let us assume that every carbohdratere searcher in the world could be provided with "standard" HPLC columns, and the columns could be replaced free of charge whenever they fail to pass certain specific performance test. Extending this notion further, let us assume that the same arrangement could be made with the HPLC instrument itsself. I believe much of the variability in the retention time may disappear or greatly diminish. Naturally this assumes that such columns and instruments can be manufactured perfectly uniformly and reproducibily. Of course these scenarios are utterly unrealistic. Nevertheless, if such demands could be made on the manufacturer of the HPLC instruments and columns, one may eventually see more reproducible and consistent data obtained by "average" workers.

More important is the establishment of an oligosaccharide bank, making oligosaccharides of well characterized structure easily available at a reasonable cost. This is another part of Dr. Yamagata's proposal, and can be pursued independent of any databases. When the reference oligosaccharides are made readily available at an affordable price range, the difficulty in identification due to variability in the HPLC data can be resolved to a large extent (although multiple methods of separation are still required). Laboratories long engaged in structural characterization of oligosaccharides in glycoconjugates have stocks of such reference compounds, and they use them effectively.

Isn't it possible to contract a laboratory to prepare reference oligosaccharides of a greater variety than is currently available commercially? There are methods available to accomplish this, and in a long run it would be far more economical than to allow numerous laboratories to prepare and characterize them individually. Since it is unrealistic to provide all the well-characterized oligosaccharides, reference libraries of key oligosaccharides should be carefully chosen to cover the needs. The reference libraries may be of different compositions to suit the needs for different occasions. For example, the library for sialylated oligosaccharides should be different from that of neutral oligosaccharides. This may not be an unattainable goal, and is occurring commercially in a small scale. What is sorely lacking is the recognition of the importance of such a project and the determination to execute it. Realistically, this should be a contract job, because it is essentially a task of reproducing what has been done already ("Wheel reinvention") and few, if any, academics will undertake such a project. When this project is organized globally, the overall cost would be even lower.

Dr. Yamagata's main thrust is to embrace the PMR data and HPLC data into one comprehensive database. Actually there are a few PMR databases compiled for various oligosaccharides. They are written in different computer languages, and
よう。この考えを更に搪張して、同しことがHPLCの機器その ものについてもいえると仮定しよう。私はそうしたら、保持時 間の変化の大部分は繁くなるか、あるいは大いに娍少すると信 じる。当然この仮定はこのようなカラムは完全に均一にかつ再 现性よく生産されることを前提とする。この僛念を更に押し進 めると、同しことがHPLCの機器そのものにも当てはまる。む ろんこの筋書きは全く現実的ではい。それにもかかわらず、 このような要求がHPLCの機械とカラムの生産者になされた ら、もっと再現性のよい、共通性のあるデータが“普通の”研 究者によって得られるであろう。

もっと重要なことは、合理的な価格て構造の判ったオリコ 諾を供給することの出来るオリコ榶バンクの確立である。これ は山形博士の提案のもう一つの部分であり、これはデータベー スとは独立に追求できる。標準オリコ格が手の届く価格範囲内 で容易に利用でるる時、HPLCデータにおける变動性に起因す る同定の困難さは大部分（多重の分敬方法が未だに必要である が）は解決てきる。複合榶質のオリコ榶の同定に長く従事して いる研究室はこれらのリフォレンス化合物のストックを持って おり、彼らはこれらを有効に利用している。

現在市販されているよりも遥かに多くのバラエティーに富

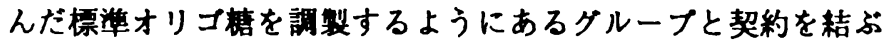
ことは可能ではないだろうか？これを成し遂げる方法があり、 長い目で見ると、無数の研究室が別々に標準オリコ榶を調製 し、同定するよりも遥かに経済的であろう。全てのよく同定さ れたオリコ糖を供給することは現実的に不可能であるのて、キ イとなるオリゴ榶のリファレンスライブラリーは実状に治う要 求をカバーするように注意樑く選ばれねばならない。リファレ ンスライブラリーは異なった要求に適するには異なった組成と なるであろう。例えは、、シアリレーテッドオリコ棓のライブラ リーは中性搪のライブラリーとは異なるかも知れない。この構 想は到達できない目標ではなく、現在小さい商業規模て起こり つつある。ただ欠けているものはこのようなブロジェクトの重 要性の認識とそれを强行する決意である。これは既知の事実の 再現であり（発明したものを再発明すること）、このようなフ ロジェクトを引き受ける研究グルーブはあまりないと思われる ので、理想的にはこれは契約による仕事であるできでる。こ のプロジェクトが世界的に組織されれば、全体のコストは安く さえなるであうう。

山形博士の主たる論点はPMRデータとHPLCデータを包括 的なデータベースにまとめることである。現実にいろんなオリ コ糖を編复したPMRデータベースが幾つか存在する。これらは 異なった言語で書かれており、操作の方法にも一貫性がない。 HPLCデータについていえば、少なくとも一つのデータベース はある固有な条件下てPA-オリコ榶のHPLCについて作成されつ つある。これはよい始まりであるが、我々はそのようなデータ 
there is no consistency in their operational modes. As to the HPLC data, at least one database is being compiled for HPLC of PA-oligosaccharide under a set of specific conditions. These are a good beginning, but we need a more concerted effort to expand and improve such databases continually. I tend to think that each of the databases (for PMR, HPLC, etc.) first has to be developed sufficiently to show its merit individually. The time is not quite ripe for merging all databases together yet.

In summary, Dr. Yamagata's proposal may be idealistic and imperfect in details, but more of us should start thinking in this direction to remove the tedium from the carbohydrate research. Shouldn't we propose such a plan as the carbohydrate researchers' answer to "human genome project"?
ベースを常に搪張し、改善するためにもっと協調的努力を必要 としている。私は各々のデータベース（PMR、HPLCなどに対 する）はまず個々に完成されるべきであると考える。全てのデ ータベースが統合される程、機は熱してはいない。

山形博士の提案は理想的であり、細かな点では不完全であ るかも知れないが、しかし桾質研究の「䫅わしさ」を取り除く この方法について我々は考え始めるべきであろう。我々は “ヒューマン ゲノムプロジェクト”に対応して糖質研究者 のこのような計画を提出すべきではなからう？
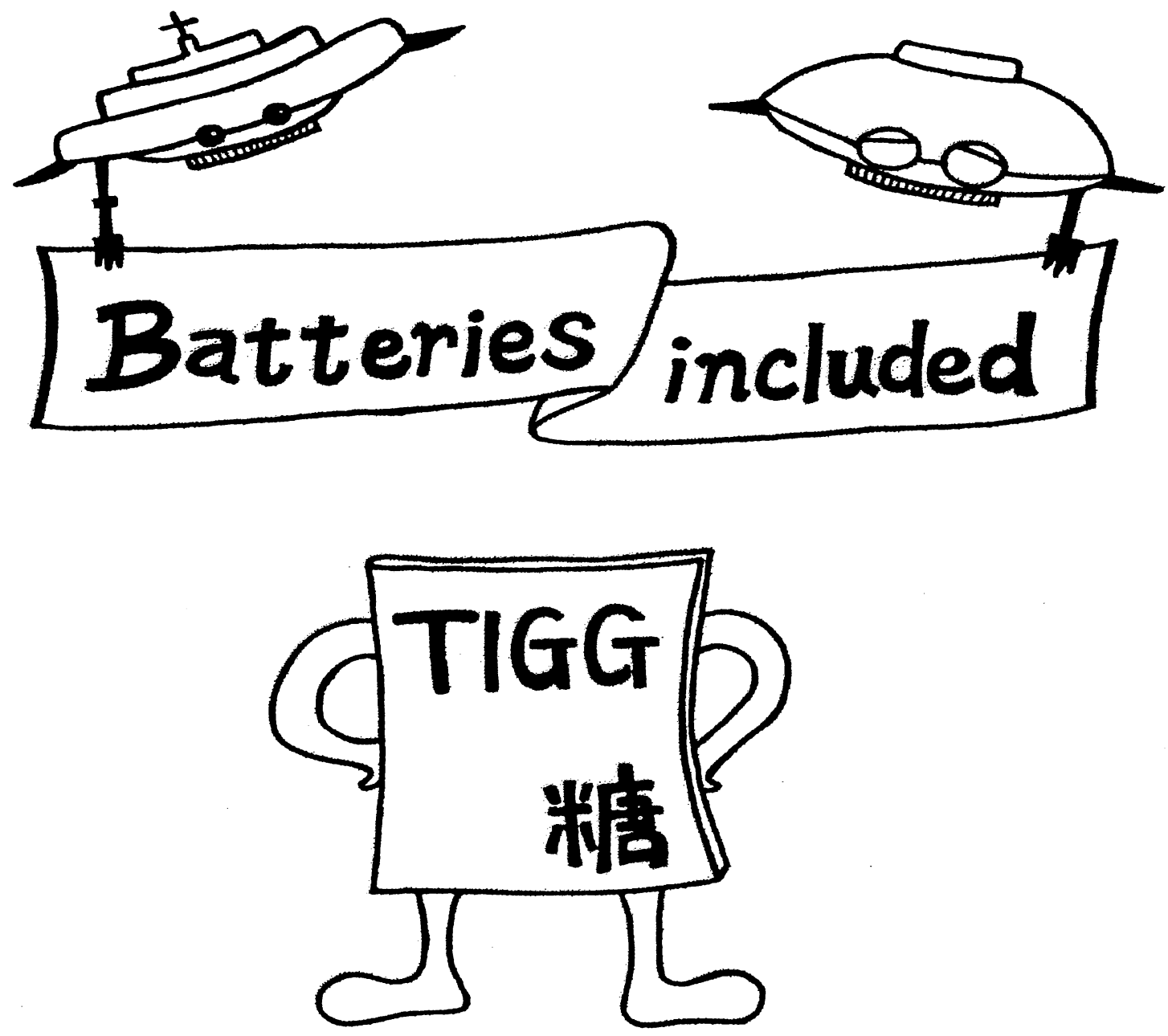